ROCZNIKI KULTUROZNAWCZE

Tom X, numer $4 \quad-\quad 2019$

DOI: http://dx.doi.org/10.18290/rkult.2019.10.4-2

\title{
EMOCJE JAKO ELEMENT STRUKTURY PRZEKAZU SAMORZĄDU LOKALNEGO W SERWISIE FACEBOOK.COM \\ STUDIUM PRZYPADKU OFICJALNEGO PROFILU MIASTA STOŁECZNEGO WARSZAWY
}

\section{WSTĘP}

Media społecznościowe (social media) są jednym z istotniejszych kanałów współczesnej komunikacji. To nie jest wyłącznie jedno- lub dwukierunkowa wymiana komunikatów, ale złożona interakcja w sieci licznych powiązań online.

Social media powstały wraz z rozwojem technologii Web 2.0, pozwalającej na tworzenie mechanizmów współpracy, partycypacji i interakcji, takich jak internetowe społeczności, blogi, kanały RSS ${ }^{1}$. Definiowanie platform społecznościowych, podmiotowo lub funkcjonalnie, sprowadza się do przedstawienia zespołu technicznych możliwości łączenia się z wieloma użytkownikami tego samego systemu. Social media pozwoliły każdej osobie na stworzenie publicznego (lub półpublicznego) profilu w ograniczonym systemie, w którym można tworzyć listy innych użytkowników, dzielić się z nimi tymi listami i połączeniami (których charakter zależy już od samego systemu, serwisu) ${ }^{2}$.

Dr hab. KRZYSZTOF KowALIK - Uniwersytet Warszawski, Wydział Dziennikarstwa, Informacji i Bibliologii, Katedra Technologii Informacyjnych Mediów; adres do korespondencji - e-mail: k.kowalik7@uw.edu.pl. ORCID: https://orcid.org/0000-0001-8511-6851.

${ }^{1}$ Tim O'Reilly, „What is Web 2.0. Design Patterns and Business Models for the Next Generation of Software", O'Reilly, dostęp 12.11.2019, http://www.oreilly.com/pub/a/web2/archive/whatis-web-20.html?page $=1$.

${ }^{2}$ Danah M. Boyd \& Nicole B. Ellison, „Social Network Sites: Definition, History, and Scholarship", Journal of Computer - Mediated Communication 13, issue 1 (October 2007): 210230. DOI: https://doi.org/10.1111/j.1083-6101.2007.00393.x. 
Łatwość tworzenia i wymiany treści ${ }^{3}$, nawiązywania nowych kontaktów, wchodzenia $\mathrm{w}$ interakcje stały się czynnikami dynamicznego rozwoju wielu platform społecznościowych. Najpopularniejsze z nich zyskały znaczne audytorium korzystających i obserwujących osób. W Polsce tego rodzaje serwisy mają wiele milionów użytkowników, np. Facebook - $21 \mathrm{mln}$, YouTube $19 \mathrm{mln}$, Instagram $-8 \mathrm{mln}^{4}$.

Należy zaznaczyć, że platformy społecznościowe udostępniają narzędzia, dzięki którym korzystający mogą publikować własne treści według pewnego ustrukturyzowanego wzorca. Natomiast osoby odczytujące przekaz mogą na niego reagować również w sposób narzucony przez serwis.

Celem niniejszego artykułu jest analiza struktury oficjalnego profilu samorządu Miasta Stołecznego Warszawy w serwisie Facebook.com oraz publikowanych treści dla stymulacji emocjonalnej użytkowników. Wzięto pod uwagę specyficzną strukturę platformy i elementy, jakie mogą wpływać na afektywność jej użytkowników. Ponieważ emocje to szczególny rodzaj stanu psychicznego o określonym kierunku (znaku emocji), intensywności i treści, zdecydowano jedynie o identyfikacji znaku emocji (pozytywne, negatywne). Osoby badane mogły jednak zaopiniować swoje wybory, które mogą wskazywać również emocje podstawowe i pochodne ${ }^{5}$.

\section{KOMUNIKACJA SAMORZĄDÓW LOKALNYCH W SERWISACH SPOŁECZNOŚCIOWYCH}

Rozwój komunikacji w społecznościach online nie mógł być niezauważony przez instytucje publiczne. Znaczna liczba osób korzystających z Sieci ${ }^{6}$ to czynnik wywołujący presję na decydentów odpowiadających za działania organizacji państwowych, samorządowych, aby aktywnie uczestniczyć w nowych mediach. Gminy, zwłaszcza duże jednostki samorządu terytorialnego, jakimi są miasta, dostrzegły potencjał tkwiący w serwisach społecznościowych, w interakcji z szeroko pojętym otoczeniem (klientami urzędu, mieszkańcami, innymi instytucjami i organizacjami). Gminni decydenci (prezy-

\footnotetext{
${ }^{3}$ User Generated Content (UGC), czyli tworzenie i wymiana własnych treści publikowanych w serwisach lub aplikacjach online.

${ }^{4}$ Zob. więcej: „Polski internet w grudniu 2019”, Polskie Badania Internetu (PBI), dostęp 12.01.2020, http://pbi.org.pl/badanie-gemius-pbi/polski-internet-w-grudniu-2019/

${ }^{5}$ Theodore D. KEMPER, „How Many Emotions Are There? Wedding the Social and the Autonomic Components", American Journal of Sociology 93, no. 2 (1987): 263-289.

${ }^{6}$ W grudniu 2019 r. w Polsce z Internetu korzystało 27,7 mln osób. Zob. więcej: „Polski internet w grudniu 2019",
} 
denci i burmistrzowie miast, wójtowie) zrozumieli, że urząd może budować „małą Ojczyznę” również poprzez nowoczesną komunikację oraz interakcję, wykorzystując także wirtualne społeczności. Takie działania mogą służyć tworzeniu wizerunku instytucji przyjaznej otoczeniu gminy i funkcjonalnie wspierać aktywność urzędu, ale także wzmacniania lokalnej społeczności. Pomimo znacznej popularności serwisów społecznościowych nie wszystkie samorządy wspierają tego rodzaju działalność. W Polsce jest 2477 gmin (302 miejskich, w tym 66 miast na prawach powiatu, 638 miejsko-wiejskich i 1537 wiejskich) ${ }^{7}$. To jednostki, których włodarze zostali wybrani w wyborach bezpośrednich. Większość dużych samorządów miejskich podjęła aktywność w nowych mediach ${ }^{8}$, w przeciwieństwie do niewielkich gmin wiejskich $^{9}$. Jakość tej komunikacji nie jest jednorodna. Jak wskazują badania, występują znaczne rozbieżności między aktywnością w social media deklarowaną oficjalnie przez gospodarzy gmin, a rzeczywistą działalnością urzędu. $\mathrm{Na}$ przykład użytkownik portalu społecznościowego często nie wie, czy obserwowany przekaz jest oficjalnym stanowiskiem gminy, czy są to treści publikowane przez osoby prywatne. W serwisach wielu samorządów, zwłaszcza małych gmin, znajdują się linki do portali social media, ale występują tylko w charakterze „ozdobnika” lub „przynęty” dla użytkowników, bo w rzeczywistości nie działają ${ }^{10}$.

Samorządy lokalne mają wiele uprawnień ustawowych sprzyjających prowadzeniu bardzo swobodnej komunikacji $\mathrm{z}$ otoczeniem. W polskim systemie medialnym są grupą właścicieli licznych instytucji i przedsięwzięć medialnych, mogącą prowadzić szeroką aktywność nie tylko informacyjną, ale również promocyjną i reklamową. Stwarza to liczne sytuacje, które można uznać za konflikty interesów ${ }^{11}$. W mediach społecznościowych taki przykład stanowi dwuznaczność

${ }^{7}$ „Samorząd terytorialny w Polsce”, ADMINISTRACJA.MSWIA.GOV.PL, dostęp 12.01.2010, http://administracja.mswia.gov.pl/adm/baza-jst/843,Samorzad-terytorialny-w-Polsce.html

${ }^{8}$ Krzysztof Kowalik, „Dialog, monolog, interakcja? Portal społecznościowy jako kanał komunikowania online samorządu gminnego. Studium przypadku miasta Kielce”, Naukowy Przegląd Dziennikarski nr 3 (78) (2018): 7-25.

${ }^{9}$ Krzysztof KowaliK, „Use of Information and Communication Technologies in Official Websites of Gminas. Are the Polish Rural and Rural - Urban Local Governments Prepared to Communicate with the Younger Generation - Digital Natives, Generation Y?", Public Administration Issues no. 5, 2019: 140-154. DOI: https://doi.org/10.17323/1999-5431-2019-0-5-140-154.

${ }^{10}$ Zob. szerzej Krzysztof KowALIK, „Obowiązki informacyjne samorządu lokalnego w epoce mediów społecznościowych oraz trendy w implementacji w serwisach WWW kanałów dystrybucji informacji. Studium przypadku gmin świętokrzyskich”, Rocznik Bibliologiczno-Prasoznawczy nr 10 (21) (2018): 119-35.

${ }^{11}$ Zob. szerzej Krzysztof KowALIK, „Media online samorządów lokalnych — nowa struktura w systemie medialnym. Próba ujęcia in statu nascendi”, Zeszyty Prasoznawcze 61, nr 3 (235) (2018): 429-448. DOI: https://doi.org/10.4467/22996362PZ.18.026.10128. 
w dysponowaniu oficjalnym profilem gminy, gdy nie wiadomo, czy służy on oficjalnym celom komunikacyjnym, promocyjnym samorządu (urzędu), czy nieformalnie osobie prezydenta, burmistrza lub wójta ${ }^{12}$.

\section{EMOCJE W PRZEKAZIE MEDIÓW}

Media, bez względu na ich rodzaj (offline, online), kanał przekazu (,papierowe", elektroniczne), narzędzie komunikacji (komunikatory, gry, social media) zawsze wzbudzały emocje. To one odgrywają istotną rolę dla odbiorcy, który zmysłami rejestruje przekaz i go dekoduje. Bez względu na to, czy jest to wpis w pamiętniku (np. offline - papierowy, online - blog), film lub post w serwisie społecznościowym, to wywołuje emocje. Rozwój technologii spowodował, że te przekazy różnią się sensorycznie, zasięgiem, semiotycznie (plus kontekst), co wpływa na afektywność odbiorców ${ }^{13}$.

Konstrukcja medialnego komunikatu zawsze była związana z ekspresją, reakcją odbiorcy na otrzymany przekaz, znajdującego się w konkretnym otoczeniu, środowisku społecznym, ekonomicznym, kulturowym ${ }^{14}$. Według McQuaila dobrze oddaje to model rytualny komunikacji, który wiąże się z przekazywaniem komunikatów we wspólnocie rozumienia i emocji ${ }^{15}$. Rozwój technologii, zwłaszcza ekspansja mediów elektronicznych, audiowizualnych i sieciowych (przede wszystkim telewizji, współcześnie również serwisów streamingujących, VOD i mających jako główny nośnik komunikatu treści multimedialne) spowodowała, że tego rodzaju przekaz stał się dla odbiorcy jednym z najbardziej angażującym emocjonalnie. Doszło do zmiany nie tylko technologicznej, ale społecznej i przede wszystkim kulturowej. To obraz i dźwięk stał się dominującym nośnikiem treści i co za tym idzie nowej stymulacji emocjonalnej. Komunikacja została zdominowana przez komunikację wizualną, ikoniczność przekazu ${ }^{16}$, powstała ikonosfera jako nowy język przekazu ${ }^{17}$.

\footnotetext{
${ }^{12}$ Krzysztof KowALIK, „Serwisy społecznościowe w komunikacji samorządów lokalnych. Studium przypadku", Naukowy Przeglad Dziennikarski nr 4 (24) (2017): 113-129.

${ }^{13}$ Joshua Meyrowitz, „Medium theory”, w The Sage handbook of media processes and effects, red. Robin L. Nabi \& Mary Beth Oliver (Los Angeles: Sage, 2009), 517-530.

${ }^{14}$ Emotions: A cultural studies reader, red. Jenifer Harding, E. Deidre Pribram (London: Routledge, 2009).

${ }^{15}$ Denis MCQUAIL, Teoria komunikowania masowego (Warszawa: Wydawnictwo Naukowe PWN, 2007), 86.

${ }^{16}$ Zob. szerzej Kenneth L. SMith, Sandra Moriarty, Keith Kenney, \& Gretchen Barbatsis, Handbook of visual communication. Theory, methods, and media (New Jersey, London: Lawrence Erlbaum Associates, Inc., Publishers, 2005).

${ }^{17}$ Mieczysław PoRĘBSKI, Ikonosfera (Warszawa: PIW, 1972), 144-145.
} 
Zmiany w konsumpcji mediów, wywołane przede wszystkim dynamicznym rozwojem narzędzi internetowych, spowodowały, że do przeżywania emocji doszedł aspekt „emocji elektronicznych”. To „,przeżywanie” za pośrednictwem komputerów, interfejsów jest nowym wyzwaniem, dającym silny impuls do odkrywania afektywności wywołanej u osób korzystających z technologii informacyjnych i komunikacyjnych ${ }^{18}$.

Środowiskiem, w którym użytkownik jest zaangażowany technologicznie oraz emocjonalnie, są serwisy społecznościowe. Dały one korzystającym możliwość komponowania własnych komunikatów, zawierających nie tylko tekst, ale także bogatą paletę elementów graficznych i multimedialnych. Sam tekst można uzupełnić o liczne „dodatki”, np. emotikony. Brak bariery w postaci konieczności posiadania specjalnych umiejętności technicznych, pozwala na łatwe publikowanie każdego rodzaju treści. Możliwość natychmiastowego reagowania (komentowania, dzielenia się, lajkowania) pozwala na synchroniczną, zmediatyzowaną ekspresję użytkowników serwisu, afektywność silnie związaną ze specyfiką technologiczną samego przekazu. Mechanizm tego działania zależy od indywidualnych potrzeb i motywów oraz specyficznych właściwości funkcjonowania platform social media ${ }^{19}$.

Warto podkreślić, że media społecznościowe to platformy działające według algorytmów, mających dostarczyć nam spersonalizowanej treści. Twórcy serwisów nierzadko kryją się z tym, że to, co użytkownik otrzymuje, jest efektem zautomatyzowanego doboru treści, powstałego wskutek eksperymentów prowadzonych w samym środowisku. Przykładem może być Facebook.com, gdzie filtrowano rodzaje przekazu, aby sprawdzić reakcje użytkowników, wpływ na ich emocje ${ }^{20}$. Eksperyment okazał się kontrowersyjny ${ }^{21}$, gdyż wykorzystano efekt „zarażenia emocjonalnego”. Badanie wspólnego przeżywania wydarzeń medialnych ma duże znaczenie, zwłaszcza w kontakcie z roz-

\footnotetext{
${ }^{18}$ Electronic emotion: the mediation of emotion via information and communication technologies, red. Jane Vincent \& Leopoldina Fortunati (Oxford: Peter Lang, Internationaler Verlag der Wissenschaften, 2009).

${ }^{19}$ Nicole C. Krämer, German Neubaum, Sabrina C. EImler, A Brief History of (Social) Cyberspace, w Cyberemotions. Collective Emotions in Cyberspace, red. Janusz A. Hołyst (Switzerland: Springer, Cham. 2017), 11-35. DOI: https://doi.org/10.1007/978-3-319-43639-5.

${ }^{20}$ Adam D. I. KRAmer, Jamie E. Guillory, \& Jeffrey T. HANCOCK, „Experimental evidence of massive-scale emotional contagion through social networks", PNAS, 111 (24) (June 17, 2014), 8788-8790. DOI: https://doi.org/10.1073/pnas.1320040111.

${ }^{21}$ Robert Booth, ,Facebook reveals news feed experiment to control emotions”, The Guardian, dostęp 12.12.2019, https://www.theguardian.com/technology/2014/jun/29/facebook-users-emotionsnews-feeds.
} 
rywką, wydarzeniami sportowymi itp. ${ }^{22}$ Co istotne, interakcja osobista i sygnały niewerbalne nie są absolutnie niezbędne do zarażenia emocjonalnego ${ }^{23}$, mogą jednak prowadzić do transferu emocji, gdzie technologia ma znaczący wpływ. Dzisiaj odbiorca komunikatu często korzysta z wielu urządzeń (lub platform społecznościowych) jednocześnie, dających poczucie wspólnotowego przeżywania wydarzenia, co może mieć wpływ na jego afektywnośćc ${ }^{24}$. Badania na platformie Facebok.com potwierdzają, że „zarażenie emocjonalne" jest istotnym elementem przekazu i reakcji, jakie są podejmowane przez osoby korzystające z mediów społecznościowych ${ }^{25}$.

Występują również zagrożenia wynikające ze specyfiki funkcjonowania tego rodzaju platform. Udostępnianie licznych danych pozwala na profilowanie użytkownika (targetowanie psychologiczne), zachęca także do prób wpływania na jego emocje, co za tym idzie - na podejmowane wybory, np. zakupowe lub polityczne ${ }^{26}$ (przykładem może być tzw. afera Cambridge Analytica i obawy płynące z manipulowania użytkownikami oraz naruszenia ich prywatności ${ }^{27}$ ).

${ }^{22}$ John E. Hocking, Duane G. MARgreiter, \& Cal Hylton, „Intra-audience effects: A field test", Human Communication Research, 3(3) 1977: 243-249. DOI: https://doi.org/10.1111/j. 1468-2958.1977. tb00522.x

${ }^{23}$ Ruoyun LIN \& Sonja UTZ, „The emotional responses of browsing Facebook: Happiness, envy, and the role of tie strength, Computers in Human Behavior 52 (November 2015): 29-38. DOI: https://doi.org/10.1016/j.chb.2015.04.064. Zob. także Bernard RIMÉ, „The Social Sharing of Emotion in Interpersonal and in Collective Situations Cyberspace”, w Cyberemotions. Collective Emotions in Cyberspace, red. Janusz A. Hołyst (Switzerland: Springer, Cham., 2017), 53-69. DOI: https://doi.org/10.1007/978-3-319-43639-5

${ }^{24}$ Elizabeth COHEN \& Alexander LANCASTER, „Individual differences in in-person and social media television coviewing: The role of emotional contagion, need to belong, and coviewing orientation", Cyberpsychology, Behavior, and Social Networking, 17(8), 512-518. DOI: https://doi.org/ 10.1089/cyber.2013.0484

${ }^{25}$ Natalya BAZARova, Yoon Choi, Victoria Schwanda SosiK, Dan Cosley \& Janis WhiTLOCK, „Social Sharing of Emotions on Facebook”, CSCW '15: Proceedings of the 18th ACM Conference on Computer Supported Cooperative Work \& Social Computing, February 2015, 154-164. DOI: https://doi.org/10.1145/2675133.2675297.

${ }^{26}$ Sandra Matz, Michal Kosinski, Gideon NAVE \& David J. STillwell, „Psychological targeting as an effective approach to digital mass persuasion", PNAS 114 (48) (November 28, 2017): 12714-12719. DOI: https://doi.org/10.1073/pnas.1710966114.

${ }^{27}$ Zob. więcej „Cambridge Analytica”, Forbes, dostęp 12.12.2019, https://www.forbes.pl/ cambridge-analytica. 


\section{METODOLOGIA BADAŃ}

$\mathrm{Na}$ podstawie przeglądu stanu literatury można stwierdzić, że występuje luka badawcza dotycząca funkcjonowania samorządów lokalnych na platformach social media, zwłaszcza diagnozująca strukturę przekazu oraz generowania przez te treści określonych emocji. Badania autora starają się wypełnić lukę poznawczą dotyczącą komunikacji tego rodzaju instytucji z otoczeniem, przede wszystkim interakcję wykorzystującą platformy społecznościowe. Dotychczasowe wyniki wykazały, że przekaz budowany na platformie Facebook.com można kategoryzować ${ }^{28}$. Ze względu na rodzaj treści publikowane przez administratorów posty zawierają elementy wpływające na reakcje użytkowników samorządowych profili. Zwłaszcza miasta intensyfikują przekaz mający wywołać emocje, więc stosują „dystrybucję emocji”,29, aby otrzymać jak największą liczbę „lajków”, komentarzy lub udostępnień.

Celem badania jest wskazanie elementów przekazu, które mogą wpływać na reakcje odbiorców treści publikowanych w oficjalnym profilu miasta w serwisie Facebook.com. To próba znalezienia czynników (bodźców tekst, wideo itd.) przekazu samorządu lokalnego, wpływających na emocje odbiorców, wyłącznie kierunków: pozytywne, negatywne (stopniowane na skali Likerta).

Postawiono następujące pytania badawcze:

1. Jakie elementy publikowane $\mathrm{w}$ oficjalnym profilu poruszają/wzbudzają emocje wśród użytkowników serwisu społecznościowego?

2. Jak struktura przekazu (konstrukcja postów) może intensyfikować emocje wyrażane przez „fanów” poprzez ich interakcję (lajki, komentarze, szerowanie, działanie w realu)?

3. Czy kategoryzacja przekazu ma znaczenie dla wskazanych kierunków emocji?

4. Jaki rodzaj interakcji „użytkowników” jest istotnym elementem wyrażenia emocji $\mathrm{w}$ odbiorze treści społecznościowych publikowanych przez samorząd lokalny?

Postawiono hipotezy główną i pomocniczą:

\footnotetext{
${ }^{28}$ Krzysztof KowALIK, „Use of Information”.

${ }^{29}$ Krzysztof Kowalik, „Dystrybucja emocji” jako forma komunikacji samorządów lokalnych w serwisie Facebook.com Próba kategoryzacji przekazu w kontekście public relations, Studia Medioznawcze 3 (74) (2018): 51-63. DOI: https://doi.org/10.33077/uw.24511617.ms.2018.3.54
} 
H: Struktura oficjalnego przekazu samorządu lokalnego wpływa na emocje odbiorców oficjalnych treści w social media, intensyfikując lub nie ich reakcje.

H1: Kategoryzacja przekazu ma wpływ na afektywność odbiorców.

Treści publikowane $\mathrm{w}$ serwisie, jako post $\mathrm{w}$ publicznym profilu samorządu miejskiego, może zawierać takie elementy jak tekst oraz materiał ilustracyjny. W warstwie tekstowej przekazu wyróżniamy sam tekst, emotikony, hasztagi ${ }^{30}$, które spełniają również funkcję interaktywną, wspomagają wyszukiwanie podobnych treści na platformach społecznościowych. W warstwie ilustracyjnej możemy wyróżnić grafikę statyczną (fotografie, infografiki w połączeniu z odnośnikami i linkami do źródeł poza serwisem), multimedialną (grafiki animowane, materiały audio i wideo wraz z linkami do źródeł zewnętrznych) oraz emotikony (obrazek „zbudowany z ustawionych w określonym porządku liter, cyfr i znaków interpunkcyjnych" służący wyrażeniu emocji ${ }^{31}$ ) lub emoji (mały obrazek, symbol wyrażający emocje ${ }^{32}$ ).

W przypadku występowania kilku elementów przekazu konieczne jest ustalenie logicznego sensu $^{33}$ kompletnej publikacji — posta (tekstu, grafiki, multimediów, emotikonów i emoji) i określenia jej kategorii Zrozumienie kontekstu jest istotnym etapem badania ${ }^{34}$. Na podstawie wymienionych elementów z oficjalnego profilu Miasta Stołecznego Warszawy w serwisie Facebook.com wybrano po jednym poście z każdej zidentyfikowanej kategorii: informacje, zaproszenia, partycypacyjne, prowokujące. Każda z nich niesie z sobą treści zróżnicowane tematycznie i intencjonalnie. Do prezentowanego badania wybrano posty, które wyróżniały się zwiększoną liczbą reakcji w stosunku do pozostałych przekazów w profilu samorządu (liczba lajków, komentarzy, szerowania). W założeniu taka selekcja powinna

\footnotetext{
${ }^{30} \mathrm{~W}$ tekście będzie wykorzystywana spolszczona wersja angielskiego słowa hashtag, czyli hasztag. Według internetowego Wielkiego słownika języka polskiego jest to „wyrażenie poprzedzone znakiem \#, które w komunikacji internetowej służy do oznaczania treści (wpisów, zdjęć, filmów), aby łatwiej można je było wyszukiwać”, dostęp: 12.12.2019, https://wsjp.pl/ index.php? id_hasla $=86506 \&$ ind $=0 \&$ w_szukaj $=$ hasztag + .

${ }^{31}$ Definicja emotikonu według tegoż Wielkiego słownika języka polskiego, dostęp: 12.12. 2019, https://wsjp.pl/ index.php?id_hasla=57204\&ind=0\&w_szukaj=emotikon

${ }^{32}$ Definition of emoji, Słownik Merriam-Webster, dostęp 12.12.2019, https://www.merriamwebster.com/dictionary/emoji

${ }^{33}$ Zob. szerzej: David Silverman, Interpretacja danych ilościowych, przeł. Małgorzata Głowacka-Grajper \& Joanna Ostrowska (Warszawa: Wydawnictwo Naukowe PWN, 2008), 59-62.

${ }^{34}$ Klaus KRIPPENDORF, Content analysis an introduction to its methodology (Thousand Oaks, London, New Delhi: SAGE, 2004), 18-21.
} 
ułatwić grupie badawczej klarowne wskazanie elementów postów, które wpływają na emocje, jakie mogą wzbudzać.

W celu weryfikacji hipotezy dokonano wyboru postów z elementami treści spełniającymi powyższe warunki, oddzielnie dla czterech kategorii opublikowanych w profilu Miasto Stołeczne Warszawy we wrześniu 2019 r.:

1. INFORMACYJNY ${ }^{35}$ — post informuje o sposobie segregacji śmieci. Tekst uzupełniony jest emoji oraz hasztagami. Zawiera również ilustrację prezentującą cztery rodzaje odpadów z hasłem informującym, jak należy je segregować.

2. PARTYCYPACYJNY ${ }^{36}$ - post zachęca do uczestniczenia w programie wymiany starych nieekologicznych kotłów grzewczych. Tekst uzupełniono o liczne emoji oraz hasztagi. Dołączono film wideo wskazujący ważność tematu oraz zachęcający do walki ze smogiem.

3. PROWOKUJACY ${ }^{37}$ - post zilustrowano wizerunkiem spacerującego kota, który powstał z fragmentów żółtego szklanego materiału przyklejonego do ściany budynku. Tekst $\mathrm{z}$ emoji oraz hasztagiem prowokuje do podjęcia działania online i wskazania, gdzie można znaleźć wizerunek kota.

4. ZAPROSZENiE ${ }^{38}$ - post $\mathrm{z}$ filmem przedstawia Multimedialny park fontann. Zaprasza na ostatnie $\mathrm{w}$ sezonie widowisko. W tekst wpleciono liczne emoji oraz linki tematyczne.

W kolejnym kroku posty były ocenione w badaniu ankietowym przeprowadzonym wśród studentów (studia dzienne i zaoczne) Wydziału Dziennikarstwa, Informacji i Bibliologii Uniwersytetu Warszawskiego. Według statystyk dotyczących polskich użytkowników Fecebook.com osoby w prze-

\footnotetext{
${ }^{35}$ Post informacyjny [zrzut ekranowy, gdyż post został usunięty z profilu samorządu], dostęp 29.09.2019, https://drive.google.com/file/d/1pDCRgO2zsDR9wwdo0Z3zsPLtWxl4byaC/ view? usp= sharing.

${ }^{36}$ Post partycypacyjny, dostęp 27.09.2019, https:/www.facebook.com/warszawa/videos/2418 61060074222/.

${ }^{37}$ Post prowokujący, dostęp 29.09.2019, https://www.facebook.com/warszawa/photos/p.1015 6742823501270/10156742823501270/?type=1\&opaqueCursor=AbqQK_QHMcVFcEDGkvWv0O onIJPGc2kheBZ2kcZBu92kaW1tp2AIVIweHEGqfEYW-HCY7Is46tzJ6z-loim_brusa3x_r02yJ88o YP78j54r_GQycEtLRm9JwyYz4CdDUALeAn26K11KGX3zoH5vvwf6amO1ik3Ht6wM1QGOpA aDbka3zfadRLtAQWbGUyEFxhi53s5Fg8mVcicZK1Grz8njOzq5Ty-hLUkUHLTEGFJ2o-Smrw Af-y_e8qth02715wyI6MYvH8wInE1BK4YkytvvBeualpnr8IdKHzHrmx7XODJsYmlT0w2c4Vibg HmiYG6S0g6eHeuY7IsjOf8XHKHwSBC6VO7yTA28GgtqEhKiziFAaDmazfm2OXuijtrkasOaPZ Rz3X615ixRSMcbAxYR1cE_iXOL28rwkf_gVrPZl-1p98JFAJ_RIBX-GLgeamCFaqeBPqUwALa 8Y pIPPoV4PsXh_evHKq92T8TEN1wUAw (dostęp 28.09.2019)

${ }^{38}$ Post zaproszenie, dostęp 28.09.2019, https://www.facebook.com/warszawa/videos/403878 $567170924 /$
} 
dziale 18-24 oraz 25-34 lat to dwie najliczniejsze grupy korzystające $\mathrm{z}$ tego serwisu $^{39}$.

W kwestionariuszu online zamieszczono pytania zamknięte i otwarte. Studenci mieli wskazać elementy wpływające na emocje pozytywne i negatywne odbiorcy oraz uzasadnić swoją opinię. Kwestionariusz wypełniło 48 studentów. Oceniali cztery posty w jednym kwestionariuszu (w kolejności wskazanej wyżej przy opisie kategorii). Skorzystano z pięciostopniowej skali Likerta.

W kwestionariuszu należało również wskazać znaczenie reakcji użytkowników (lajki, komentarze, szerowanie, działanie w świecie rzeczywistym w skrócie zwanym dalej „w realu”) i ich znaczenie dla zaangażowania emocjonalnego odbiorcy. Wszystkie ankietowane osoby zadeklarowały korzystanie z serwisu Facebook.com.

\section{WYNIKI BADANIA}

\section{POST INFORMACYJNY}

Post informacyjny wzbudził pozytywne emocje u blisko $40 \%$ osób. Zdecydowana jednak większość respondentów wskazała, że przekaz nie wzbudza żadnych emocji, a tylko u 6,3\% post wywołał emocje negatywne (zob. Wykres 1).

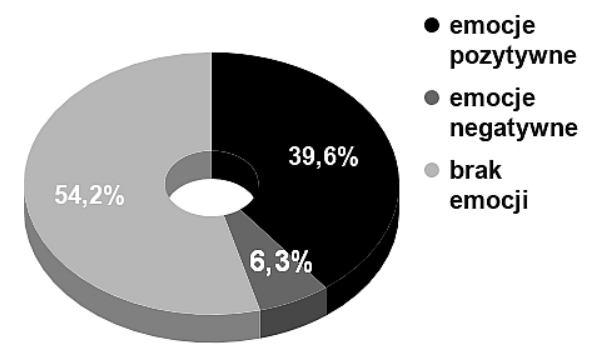

Wykres 1. Post Informacyjny. Rodzaj wzbudzonych emocji.

Dla osób biorących udział $\mathrm{w}$ ankiecie jednym $\mathrm{z}$ najważniejszych czynników wpływających na pozytywny odbiór posta była istotność poruszanego

${ }^{39}$ Agnieszka ChabrzyK, Julia KaŁużyńSKa, Przemysław Rosa, Andrzej Suhov \& Monika TureK, „Facebook”, Przewodnik po social media w Polsce 2019/2020, iab Polska 2019, 6, dostęp: 01.01.2020, https://iab.org.pl/wp-content/uploads/2020/01/IAB-Przewodnik-po-Social-Media-wPolsce-2019-2020.pdf. 
tematu, znaczenie ekologicznego sposobu życia. U 16 osób temat wzbudził emocje od pozytywnych do niezwykle pozytywnych (zob. Wykres 1A). Respondenci podkreślali, że niezbędne jest promowanie pozytywnych nawyków i uczenie innych, jak prawidłowo segregować śmieci. Zauważono również „ciekawe poruszenie tematu”40, czyli redakcję tekstu wiążącą segregację śmieci z ulubionymi posiłkami na chłodne wieczory. „Najpierw nawiązuje do kulinariów, a przecież każdy lubi jeść (zwłaszcza smaczne potrawy :)), nieważne czy jest się szarym obywatelem czy przedstawicielem władz miasta (zmniejszenie dystansu między nadawcą a odbiorcą komunikatu)". Zauważono również, że „Miasto Stołeczne Warszawa [...] w kreatywny sposób pokazuje odbiorcom, jak prawidłowo segregować śmieci, a co za tym idzie - dbać o planetę". W kolejnym komentarzu wskazano na istotność poszczególnych elementów treści: „Post przywołał na myśl smaki, które pozytywnie mi się kojarzą (czekolada, miód, dynia), przy okazji ucieszyłam się, że porusza temat segregacji odpadów (jestem ogromną zwolenniczką segregacji)”. Respondentka, jak większość pytanych, docenia sposób redakcji tekstu, stylu (zob. Wykres 1A).

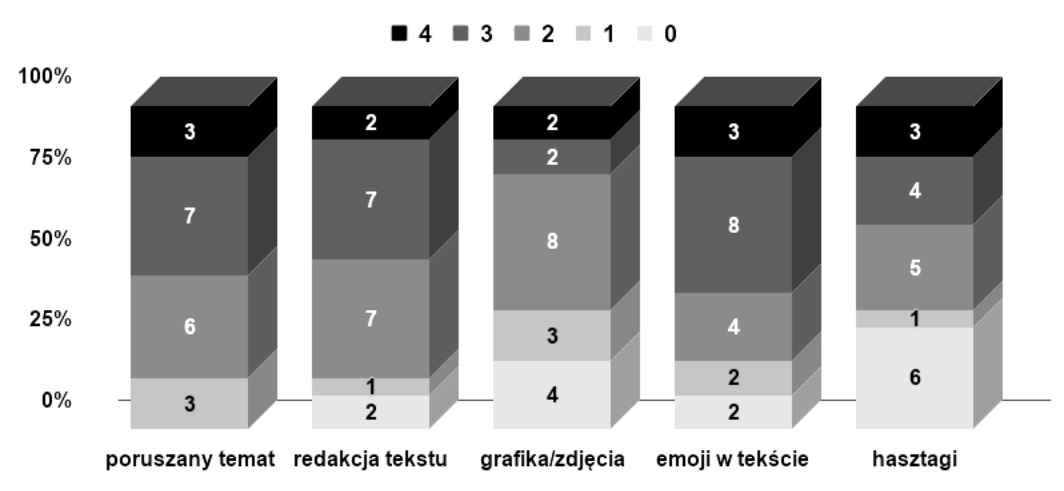

Wykres 1A. Post informacyjny. Wskazanie elementów przekazu, które poruszyły respondentów pozytywnie.

Ocena w skali: 0 - nie wzbudza emocji, 1 - nieznaczne pozytywne emocje, 2 - pozytywne emocje, 3 - bardzo pozytywne emocje, 4 — wzbudza niezwykle pozytywne emocje. Na słupkach liczba odpowiedzi.

Jako czynnik wpływający na pozytywne emocje podano między innymi zrozumiałość, fakt, że post jest „napisany w stylu młodzieżowym, zabawnie,

\footnotetext{
${ }^{40}$ Prezentowane cytaty pochodzą z opinii badanych. Zachowano oryginalny styl, ale skorygowano błędy ortograficzne.
} 
lekko”, „zaczyna się od prostego pytania, rodem z restauracji, co jest bardzo ciekawym zabiegiem, przywołującym pozytywne skojarzenia", informacje przekazane „prostym językiem, ale atrakcyjnie”. „Dodatkowo można poczuć się tak, jak gdyby pisał go nasz znajomy, a nie pracownicy urzędu”, ,jest przyjemniej odbierany przez użytkowników (szczególnie młodych), niż gdyby został napisany formalnym językiem" - czytamy w opiniach ankietowanych.

Studenci zwrócili uwagę również na znaczenie opublikowanego zdjęcia oraz użycie emoji. Na skali te dwa elementy są silnie zaakcentowane (zob. Wykres 1A). W opiniach podkreślano znaczenie elementów graficznych na pozytywny odbiór całego przekazu. „Dołączone zdjęcia działają na wyobraźnię, powodują, że treść komunikatu bardziej utrwala się w naszej pamięci. Przedstawiają produkty spożywcze, które są nam bliskie, zwłaszcza w okresie jesienno-zimowym (przez co grafika jest również bardzo aktualna)" — czytamy w opiniach. Respondenci podkreślali: „grafika sprawia, że człowiek jest zainteresowany postem i przeczyta powyższy tekst". W podobnym tonie wypowiadano się na temat emoji: „wyrażają emocje. Jest to super dopełnienie jakiejś wypowiedzi”, a „post staje się mniej nudny i surowy, dużo nowoczesnych organizacji używa tego sposobu pisania, a samorządy idą również tym tropem”. Dzięki nim „od razu ten post kojarzy mi się z czymś dobrym, sprawiającym radość".

Jak wspomniano, 6,3\% ankietowanych studentów wskazało jednak, że przekaz wzbudzał u nich negatywne emocje. Takie elementy jak redakcja tekstu i grafika wywoływały najsilniejsze negatywne emocje (zob. Wykres 1B).

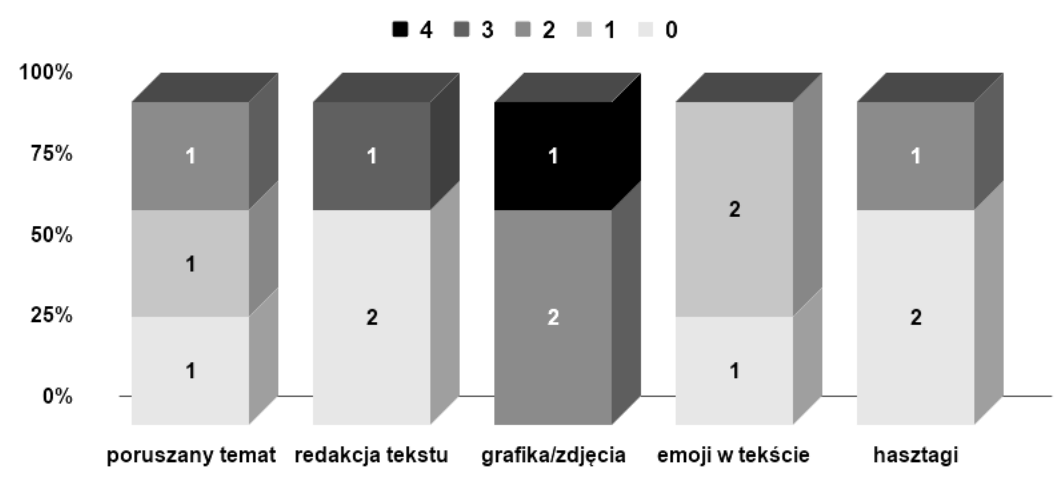

Wykres 1B. Post informacysny. Wskazanie elementów przekazu, które poruszyły respondentów negatywnie.

Ocena w skali: 0 - nie wzbudza emocji, 1 - nieznaczne negatywne emocje, 2 - negatywne emocje, 3 - bardzo negatywne emocje, 4 — wzbudza niezwykle negatywne emocje. Na słupkach liczba odpowiedzi. 
O ile odpowiedzi rozłożyły się równomiernie na wszystkie elementy, to respondenci zwracali uwagę przede wszystkim na estetyczną stronę przekazu — tak tekstu, jak tez ilustracji. „Znacznym minusem jest po prostu jakość i dobór grafiki tego posta”, bo „zdjęcia odpadów nie mogą powodować dobrych emocji".

$\mathrm{Na}$ brak emocji związanych z przekazem wskazało 54,2\% ankietowanych. Większość z nich jednak podkreślało, że „temat segregowania odpadów powinien budzić bardzo silne emocje, ponieważ porusza bardzo ważny problem bagatelizowany przez wielu ludzi”, „dotyczy [...] ekologii, a co za tym idzie naszej przyszłości”. Interesujące są negatywne opinie dotyczące redakcji tekstu, która jest „standardowa”, „zbyt sztampowa”, a „powinna budzić emocje. (Pozytywne i lekko kontrowersyjne). Więcej osób zainteresuje się wtedy tematem posta. Tekst powinien się czymś wyróżniać, czymś nas zachęcić sprawić, że sami stwierdzimy, że poruszany temat dotyczy też nas".

Kilka osób podkreśliło, że ważniejszym elementem jest grafika, tekst jest tylko uzupełnieniem treści: „lepiej jest dodać 2-3 emotikony, niż pisać kolejne długie zdania. Powinny budzić pozytywne emocje, lecz trzeba też z tym uważać, bo nadmiar emotikonów denerwuje i drażni, a to wtedy odpycha odbiorcę". Chociaż nie zabrakło opinii, że „powinny budzić pewne emocje, bo to one są emocjami. Mogą budzić pozytywne lub negatywne emocje w zależności od kontekstu”, ,są sugestywne, ale dla mnie dziecinne i niepoważne $\mathrm{w}$ istotnej społecznie tematyce, pasują do rozmówek towarzyskich, nie przekonują mnie”. Ankietowani podkreślali, że grafika „stanowi główną część komunikatu, ma przyciągać uwagę, [...] wzbudzać pozytywne emocje, które zmotywowałyby i zachęciły do zmiany na lepsze". Podobne wezwanie do publikowania grafiki zachęcającej do pozytywnych emocji dominuje w komentarzach z negatywną oceną.

\section{POST PARTYCYPACYJNY}

Ten rodzaj posta wzbudził pozytywne emocje u dwóch trzecich ankietowanych, ponad jedna piąta uważa, że nie wzbudza emocji, ale jedna dziesiąta uważa go za przekaz budzący negatywne odczucia (zob. Wykres 2). 


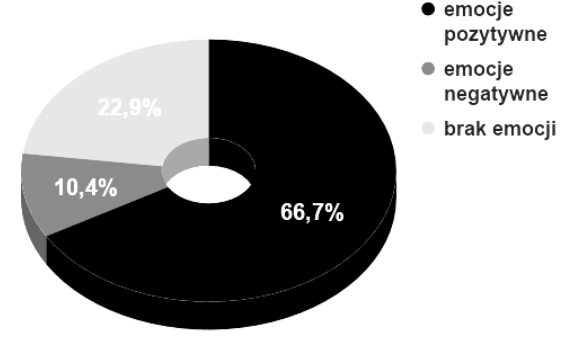

Wykres 2. POSt PARTYCYPacyjny. Rodzaj wzbudzonych emocji

Osoby komentujące post jako pozytywny (32) wskazały, że elementem wzbudzającym takie emocje jest tematyka smogu i jego zapobieganie, pokazuje „rozwiązanie aktualnego tematu, który jest bardzo ważny dla naszego kraju”. „Ogłasza coś, co może realnie wpłynąć na życie ludzi”, „wywołuje [...] poczucie swego rodzaju bezpieczeństwa, że ktoś myśli o moim zdrowiu w kontekście przyszłościowym. „Mówi o pozytywnych działaniach dla środowiska, co uważam za bardzo rozsądne i warte propagowania". Wskazali również na praktyczny wymiar treści, ,ponieważ miło dowiedzieć się, że ludzie będą mogli liczyć na pokrycie kosztów związanych z walką ze smogiem”.

Poza poruszanym tematem istotną rolę $\mathrm{w}$ przekazie odgrywa element redakcji tekstu (zob. Wykres 2A). Znaczna liczba osób (28 z 48 ankietowanych) zaopiniowała ten czynnik jako wzbudzający emocje pozytywne, bardzo pozytywne oraz niezwykle pozytywne.

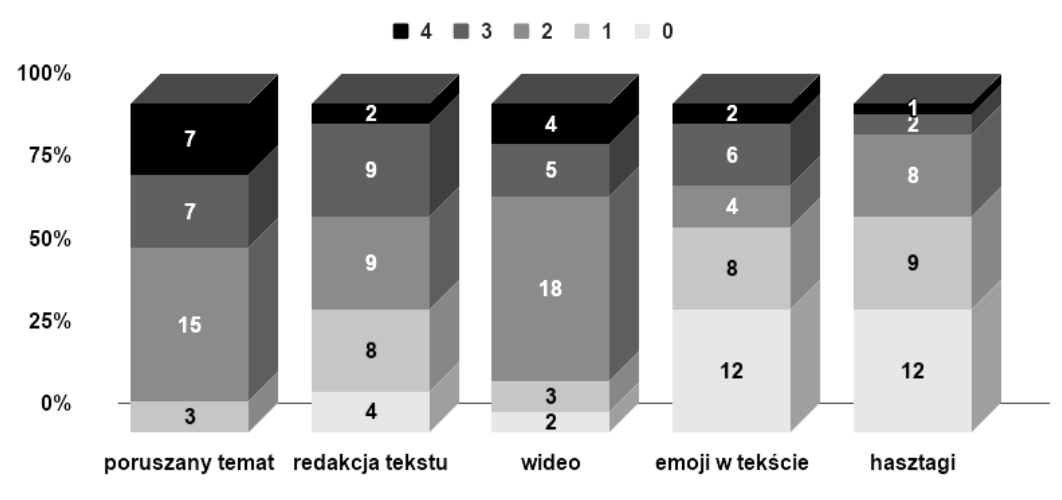

Wykres 2A. Post PaRtycypacyjny. Wskazanie elementów przekazu, które poruszyły respondentów pozytywnie.

Ocena w skali: 0 - nie wzbudza emocji, 1 - nieznaczne pozytywne emocje, 2 - pozytywne emocje, 3 - bardzo pozytywne emocje, 4 — wzbudza niezwykle pozytywne emocje. Na słupkach liczba odpowiedzi. 
W komentarzach jako ważny wskazano ,prosty, zrozumiały przekaz informacji napisany w ciekawy sposób”. „Jasno widać w nim określony cel. Zachęca do zainteresowania się tematem oraz do obejrzenia filmiku". Należy zaznaczyć, że ankietowani podkreślali „brak ubarwień”, „trudnych słów, każdy może go zrozumieć”, „przyjemnie się go czyta” i jasno mówi o pomocy proponowanej przez miasto. Ankietowani zwrócili również uwagę na takie zwroty, jak „będziecie mogli”, „ty”, co skraca dystans. Konkretna treść jest nastawiona na „komunikację i swobodny kontakt z czytelnikami”.

Znaczna część osób zwróciła uwagę na istotność elementu, jakim jest wideo (zob. Wykres 2A). Analizując komentarze ankietowanych, można ich opinie określić treścią jednej z wypowiedzi: „najbardziej rozwiązuje temat postu". Studenci podkreślają, że film budzi ich pozytywne emocje z powodu nie tylko klarownego przedstawienia tematu (,zdania w filmiku są bardzo krótkie i proste, przez co dają się zapamiętać", ale również jego profesjonalnego wykonania, ,przekonującego przekazu”. W połączeniu z wykorzystanym w tekście „czerwonym wykrzyknikom” przyciągają uwagę czytelnika. Te argumenty przeważają w ocenie emoji. Podobne opinie towarzyszą hasztagom, jako elementom pozytywnie wpływających na akcję walki ze smogiem i ułatwiających znalezienie tematu w serwisie. Wiele osób jednak podkreśla, że nie zwraca uwagi na hasztagi, pomimo wyrażenia opinii o pozytywnym oddziaływaniu na emocje związane z postem.

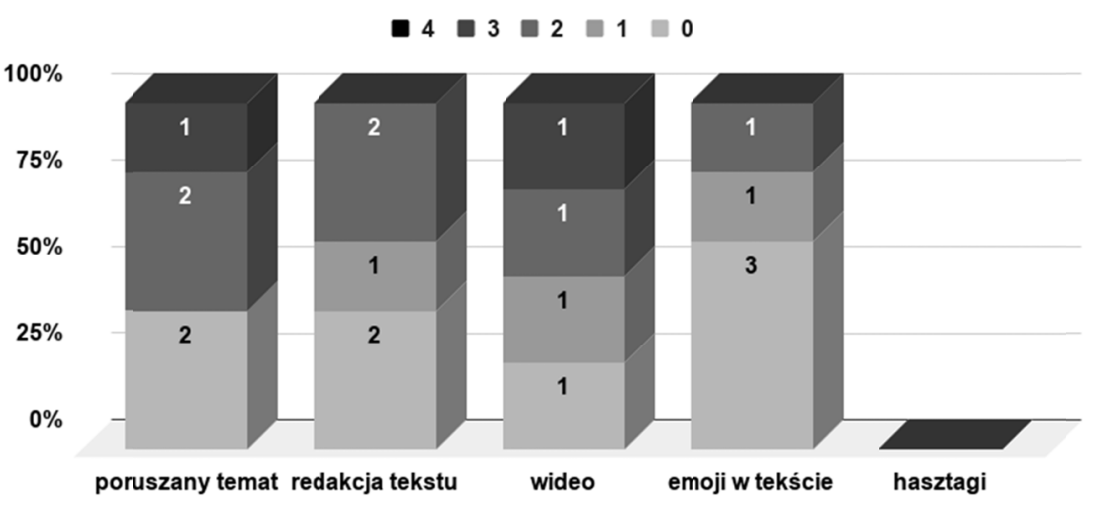

Wykres 2B. Post PARTyCrpacyjny. Wskazanie elementów przekazu, które poruszyły respondentów negatywnie.

Ocena w skali: 0 - nie wzbudza emocji, 1 - nieznaczne negatywne emocje, 2 - negatywne emocje, 3 - bardzo negatywne emocje, 4 — wzbudza niezwykle negatywne emocje. Na słupkach liczba odpowiedzi. 
Post wzbudził negatywne emocje u 10,4\% ankietowanych osób. Dominują opinie związane $\mathrm{z}$ samym tematem i stwierdzeniem, że sytuacja w sprawie smogu jest aż tak zła (zob. Wykres 2B).

Tego rodzaje komentarze przeważają w ocenie elementów wpływających na negatywne odczucia. Głównie dotyczą redakcji tekstu, który „powinienem być bardziej stanowczy w przypadku tego zagadnienia”. Zarzucono także przeciętność języka (zwłaszcza słowa „kopciuch”) i brak elementów wyróżniających treść. Czynnikiem negatywnie wpływającym jest zbyt duża liczba emoji, które „irytują i przeszkadzają w odbieraniu komunikatu”. Są „nawet niepoważne, zmniejszają rangę sprawy". Natomiast wśród negatywnych emocji związanych z wideo podkreślono dwa elementy: „nie jest ciekawe” oraz, że „poruszony problem bardzo mnie dotyka” i „daje do myślenia”.

Wokół ambiwalentnych emocji związanych z postem dominuje brak ciekawszej formy przedstawienia tematu, nadużywania emoji, „bezemocjonalnego" filmu oraz zbyt częstego występowania problemu w codziennym otoczeniu ankietowanych.

\section{POST PROWOKUJĄCY}

Post przedstawiający kota wywołał pozytywne emocje u $64,6 \%$ badanych, $29,2 \%$ nie deklarowało żadnych reakcji, a $6,3 \%$ miało negatywne wrażenia (zob. Wykres 3).

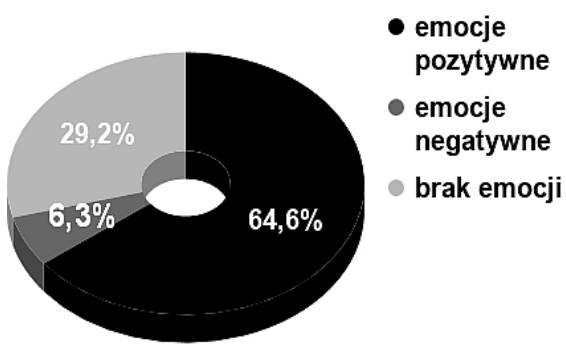

Wykres 3. POSt PROWOKUjący. Rodzaj wzbudzonych emocji.

W komentarzach potwierdzających pozytywne emocje czytamy głównie o tym, że ,jest przyjemny do obejrzenia”, występuje „dobra gra słów”, „ociepla wizerunek miasta, zbliża użytkowników, „powoduje chyba uniwersalnie pozytywne odczucia wśród właścicieli i fanów czworonogów". Post chwalony jest za kreatywność, kolorystykę i oryginalność. „Poprawia humor”, ,ponieważ na obrazku jest kotek”, „bo kocham koty”. 
Podobne opinie dotyczą redakcji tekstu, która zachęca do interakcji z miastem (zob. Wykres 3A). Badanym osobom spodobała się gra słowna („marKOTni”), prosty, młodzieżowy i zabawny język. Dominuje pozytywna ocena stylu skracającego dystans — „lepiej nie można wymyślić”. Potwierdzają to wskazania osób oceniających grafikę na skali (Wykres 3A).

Ankietowani podkreślali, że pozytywne emocje wzmacnia załączona fotografia. „Jest spójna z tekstem”, również kreatywna. Nawiązanie do zwierząt, sympatii do nich jest głównym motywem w opiniach — "słodkie i piękne” (najwięcej najwyższych ocen na skali -8 osób).

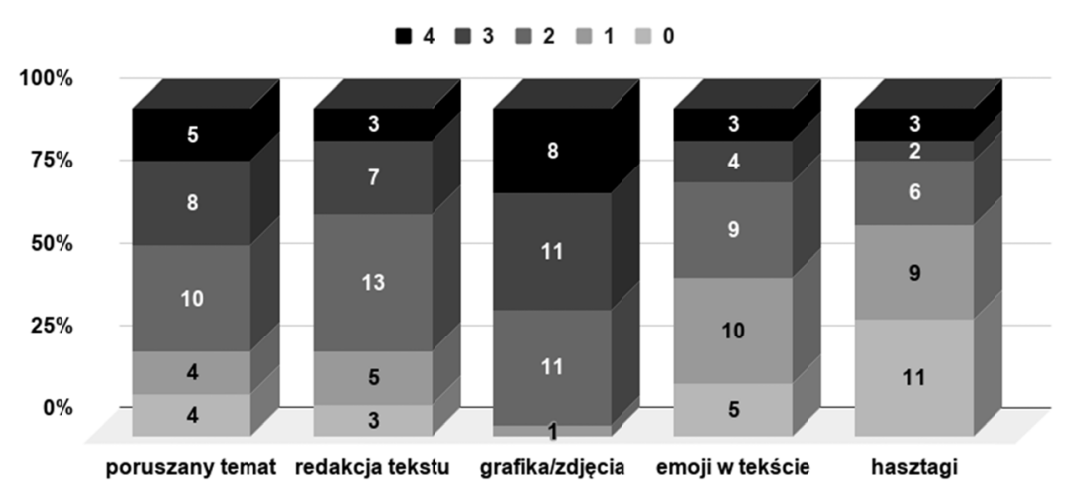

Wykres 3A. POSt PRowokujący. Wskazanie elementów przekazu, które poruszyły respondentów pozytywnie.

Ocena w skali: 0 - nie wzbudza emocji, 1 - nieznaczne pozytywne emocje, 2 - pozytywne emocje, 3 - bardzo pozytywne emocje, 4 - wzbudza niezwykle pozytywne emocje. Na słupkach liczba odpowiedzi.

Analiza wypowiedzi na temat hasztagów (najwięcej opinii: „nie wzbudzają żadnych emocji” - 11 osób) i wykorzystania emoji jest podobna do opinii zawartych przy poprzednich postach. Część osób potwierdza sens oraz trafność ich publikacji, część jest przeciwna i wręcz podkreśla, że ,ich nie dostrzega".

W komentarzach dotyczących negatywnych emocji (zob. Wykres 3B) dominują przeciwnicy kotów oraz stylu przekazu, jaki został skonstruowany na profilu samorządu: „nie rozumiem celu tego postu na stronie Miasta Stołecznego Warszawy, bardziej pasuje mi on na fanpage samorozwojowy/ couchingowy, a nie reprezentatywną dla miasta stronę". Autor uznał ten post za stratę czasu. Takie zarzuty pojawiają się również przy ocenie redakcji tekstu oraz załączonej grafiki. 


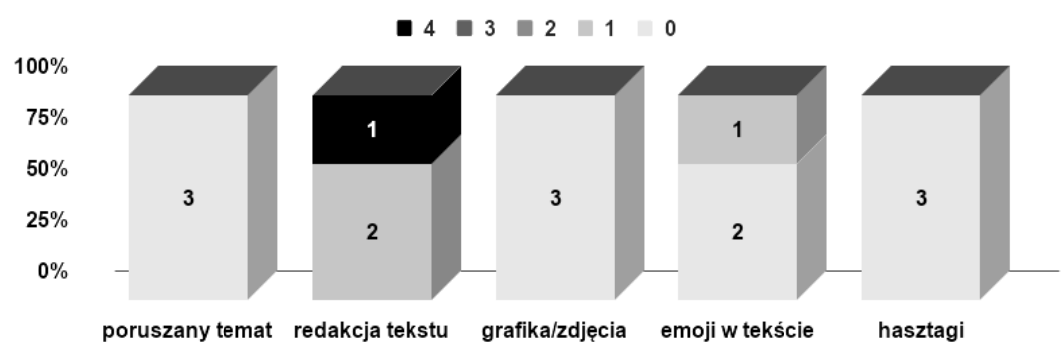

Wykres 3B. P0St PRowokujący. Wskazanie elementów przekazu, które poruszyły respondentów negatywnie.

Ocena w skali: 0 - nie wzbudza emocji, 1 - nieznaczne negatywne emocje, 2 - negatywne emocje, 3 - bardzo negatywne emocje, 4 — wzbudza niezwykle negatywne emocje. Na słupkach liczba odpowiedzi.

Natomiast grupa badanych, która zaznaczyła ambiwalentny charakter posta, podkreśla, że przekaz nie ma wiele do zaoferowania — "nic ciekawego”, „kot nie jest taki słodki” i „zaśmieca tablice”.

\section{POST ZAPRASZAJĄCY}

Ten rodzaj przekazu nie wywołał żadnych negatywnych emocji - u 70,8\% badanych pozytywne, u 29,2\% brak jakichkolwiek emocji (zob. Wykres 4).

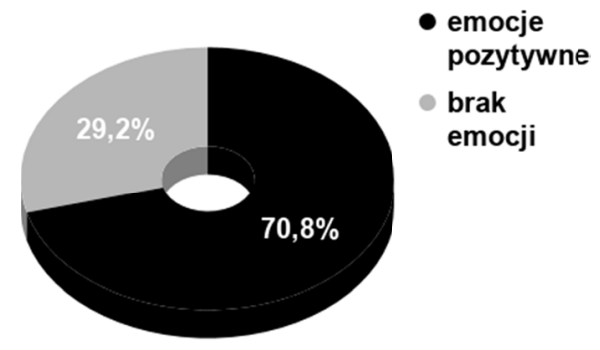

Wykres 4. POSt ZAPRASZający. Rodzaj wzbudzonych emocji.

Badani zwracali uwagę, że post ma charakter uniwersalny i „pasuje wszystkim”. „Jest związany z rozrywkowym wrażeniem”, „to interesująca propozycja na spędzenie wieczoru ze znajomymi”. Zauważali również „,̇artobliwy sposób" przekazu oraz promowanie interesujących wydarzeń w mieście.

Znaczna liczba osób komentujących treść tekstu doceniło interesującą redakcję nawiązującą do piosenki i legendarnych postaci (zob. Wykres 4A). Uznali jego konstrukcję za „przyjemną w odbiorze”, styl zaś „bardzo 
przystępny", który przyciąga i bawi. Warto zwrócić uwagę, że w opiniach zauważono atrakcyjne wideo (najwięcej emocji pozytywnych, bardzo pozytywnych i niezwykle pozytywnych - 33 osoby), które ,jest przyjemne dla oka i ucha”. Film przedstawia „piękne show, uśmiechający się ludzie — uderza w emocje".

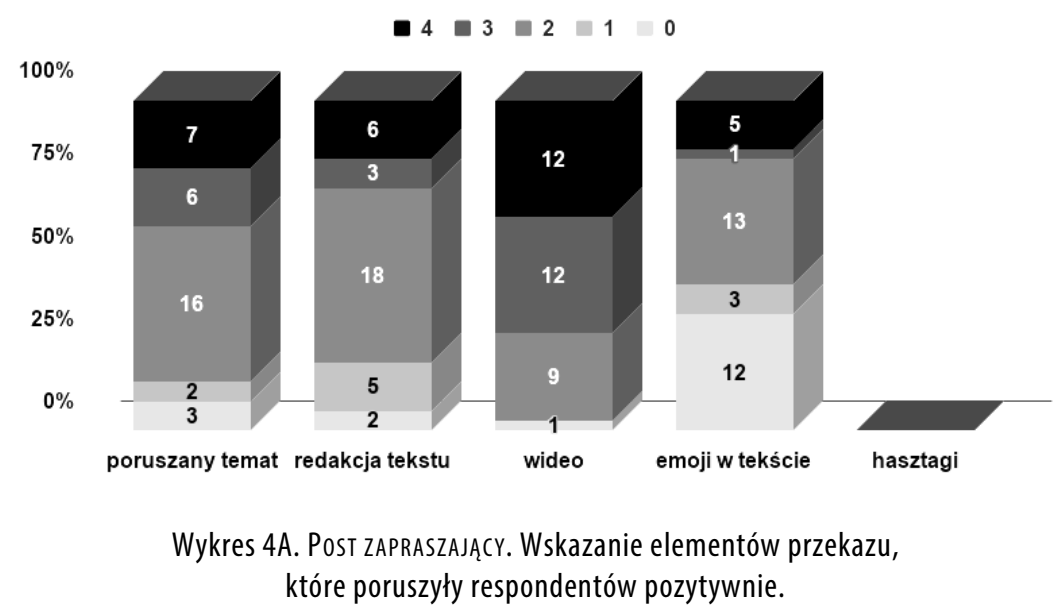

Ocena w skali: 0 - nie wzbudza emocji, 1 - nieznaczne pozytywne emocje, 2 - pozytywne emocje, 3 - bardzo pozytywne emocje, 4 — wzbudza niezwykle pozytywne emocje. Na słupkach liczba odpowiedzi.

Badane osoby podkreślają, że pozytywne emocje zwiększają wspomnienia osobistego uczestnictwa w pokazie. Inne czynniki zachęcające do obejrzenia to przede wszystkim „entuzjastyczna reakcja widowni”, „film mocno nakręca emocje".

Podobnie jak w poprzednich postach powtarzają się opinie dotyczące wykorzystania emoji. Osoby, które pozytywnie oceniają ten element podkreślają ich odpowiedni dobór, osoby zaś przeciwne ich użyciu nie zwracają na nie uwagi lub uważają je wręcz za zbędne.

\section{BADANIE REAKCJI NA PUBLIKOWANE TREŚCI}

W ankiecie osoby badane miały wskazać, jaki rodzaj aktywności świadczy o zaangażowaniu emocjonalnym użytkownika w opublikowane treści. Wyniki wskazują, że to działanie w realu jest czynnikiem najbardziej istotnym (29 osób, zob. Wykres 5). 


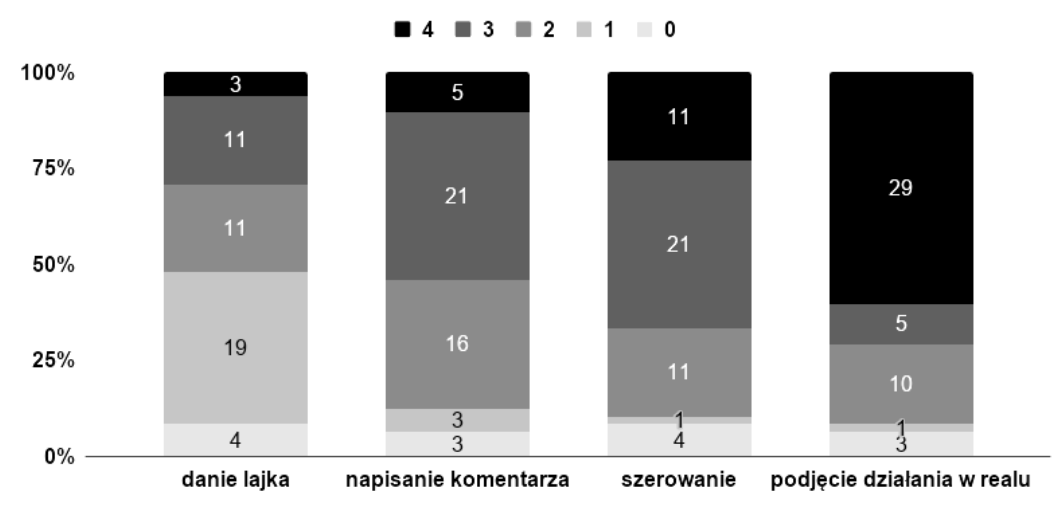

Wykres 5. Porównanie działania ze względu na znaczenie dla przekazu

Ocena w skali: 0 - bez znaczenia, 1 - mało ważne, 2 - ważne, 3 - bardzo ważne, 4 - najważniejsze. Na słupkach liczba odpowiedzi.

„Jeśli użytkownik ma się zaangażować w to, co miasto napisało, to lajki tak naprawdę nie mają znaczenia. Najważniejsze jest działanie użytkownika w Realu” - czytamy w komentarzach ankietowanych. „I myślę że ilość realnych działań jest najlepszym miernikiem dotarcia miasta do użytkowników”. W drugiej kolejności na skali znalazło się „napisanie komentarza”, ocenione jako ważne, bardzo ważne i najważniejsze (wskazanie 42 osób spośród 48 ankietowanych). Uzasadniają to zamieszczone opinie: „komentarze chyba najbardziej oddają to, co czuje użytkownik”, ,jeśli ludzie je piszą, znaczy, że ich naprawdę interesuje ten temat”, mogą „przedstawić swój punkt widzenia, opisać emocje". Znaczne zaangażowanie emocjonalne wskazano również przy dzieleniu się postami. Tylko 5 osób zaznaczyło ten typ działania jako „bez znaczenia” i „mało ważne”. W opiniach podkreślono, że „Szerowanie jest niczym powiedzenie światu, emocjonalnie: myślę podobnie, to jest dla mnie ważne, chcę poświęcić przestrzeń mojego Facebooka właśnie na ten aspekt”. To „szerowanie i podejmowanie działania w realu świadczą o zaangażowaniu emocjonalnym użytkownika”. Danie „lajka” przy publikacji nie jest bardzo istotnym elementem. Najwięcej osób oceniających 19 - uznało takie działanie za mało ważne, 4 określiły jako „bez znaczenia”. „Lajkowanie” w opiniach badanych uchodzi za reakcję na tyle szybką i prostą, że pozwala „wirtualnie bardzo łatwo się zaangażować. „Lajk” może dać każdy, musi jednał być silna reakcja emocjonalna, żeby użytkownik faktycznie podjął działanie w realu". Taką ocenę potwierdza wiele komentarzy: „like oznacza mała aktywność, użytkownik został chwilowo poruszony, ale 
zaraz może o tym zapomnieć”, „danie lajka jest mało ważne, ponieważ często je dajemy wielu postom, nie przywiązując do tego wielkiej wagi”.

\section{WNIOSKI}

Badania struktury przekazu Miasta Stołecznego Warszawa potwierdziło postawioną hipotezę. Konstrukcja postów, publikacja wyszczególnionych w ankiecie elementów wpływa na emocjonalny odbiór oficjalnych treści zamieszczonych na profilu samorządu.

Porównanie wywoływanych emocji w poszczególnych kategoriach przekazu wskazuje, że post informacyjny wzbudzał najmniej pozytywnych, ale najwięcej ambiwalentnych (zob. Wykres 6). W pozostałych kategoriach zanotowano znaczny wzrost pozytywnego odbioru przez użytkowników serwisu społecznościowego - w poście partycypacyjnym, jak i prowokującym. Interesujące reakcje wywołał post zapraszający, który nie powodował żadnych emocji negatywnych, czego powodem może być atrakcyjna forma prezentacji (wideo) i temat określony jako „rozrywkowy”.

Badanie wykazuje, że istotnymi czynnikami odbioru emocji jest konstrukcja całego przekazu. Poczynając od treści, która przede wszystkim powinna poruszać ważne dla miasta problemy, ale koniecznie w sposób kreatywny, co podkreślali ankietowani. Redakcja tekstu powinna być dostosowana do języka używanego przez młode osoby, gdyż wiele z nich korzysta z mediów społecznościowych. We wszystkich kategoriach wskazywano na grafikę lub wideo jako czynniki mające bardzo duży wpływ na emocje w odbiorze publikowanego posta. Dobór tych elementów może mieć wręcz kluczowy wpływ na znaczną dwubiegunowość opinii (np. przy poście zapraszającym, w mniejszym stopniu w postach prowokującym i partycypacyjnym). Wykorzystanie „sztampowości” powoduje, że ważny temat dla społeczności wywołuje negatywne emocje, a powinien zaciekawiać, pozytywnie wpływać na większą liczbę odbiorców.

Interesujące wyniki przyniosło badanie wpływu emoji. Budzą one podobne emocje jak zastosowanie hasztagów we wszystkich przekazach (z wyłączeniem zapraszającego, gdzie się nie pojawiły). W części opinii dotyczących emoji można doszukać się metafory do powiedzenia, że ,jedno zdjęcie zastąpi tysiąc słów" - jedno, dwa emoji może zastąpić długi opis. W wielu jednak ocenach mają one istotny wpływ na wywołanie określonych emocji, najczęściej publikowanych dla wywołania pozytywnych reakcji. Osoby, które 
wskazały negatywne emocje podkreślały ich „nadużycie” jako dziecinne, niepasujące do poważnych tematów (np. post partycypacyjny).

Hasztagi nie wywoływały tak skrajnych emocji co do użycia jak emoji. Ankietowani podkreślali ich praktyczny wymiar, jako ważny element ułatwiający wyszukiwanie $\mathrm{w}$ serwisie podobnych treści. Z drugiej strony nawiązywali do ich „instagramowości”, czyli utożsamiania z serwisem kładącym większy nacisk na dystrybucję zdjęć i tematów rozrywkowych. W opiniach pojawiały się także komentarze o „niedostrzeganiu hasztagów i emoji” w treści postów.

Ważnym elementem badania było wskazanie przez użytkowników istotności reakcji na oficjalne przekazy samorządu lokalnego. Wyniki pokazuję, że najważniejszym czynnikiem jest podjęcie przez użytkownika serwisu działania w realnym świecie. Drugim co do istotności okazały się aktywności związane z dzieleniem się informacji oraz napisaniem komentarza do opublikowanego przekazu. Najmniej ważnym elementem jest „danie lajka” pod postem. W opiniach badane osoby wskazywały, że wynika to z możliwości zaangażowania się $\mathrm{w}$ treści na profilu, w temat poruszany $\mathrm{w}$ poście. Komentowanie i dzielenie się publikacją może wskazywać na zaangażowanie emocjonalne online, zaś działanie w rzeczywistym świecie to już prezentowanie emocjonalnego związku z przedstawionym w poście problemem.

Jako podsumowanie istotności powyższych czynników trafna wydaje się wypowiedź jednej z ankietowanych osób:

1. Podjęcie działania ukazuje, że post realnie zaangażował emocjonalnie użytkownika. 2. Udostępnianie ukazuje, że odbiorca jest na tyle poruszony, że chce podzielić się tym z kimś innym. 3. Podobnie jest z komentarzem, odbiorca chce odpowiedzieć na dany temat, bo musi być emocjonalnie zaangażowany. 4. Like oznacza mała aktywność, użytkownik został chwilowo poruszony, ale zaraz może o tym zapomnieć.

Interesujące jest porównanie wyrażonych emocji dotyczących badanych przekazów z reakcjami jakie podjęłyby ankietowane osoby (zob. Wykres 6). 


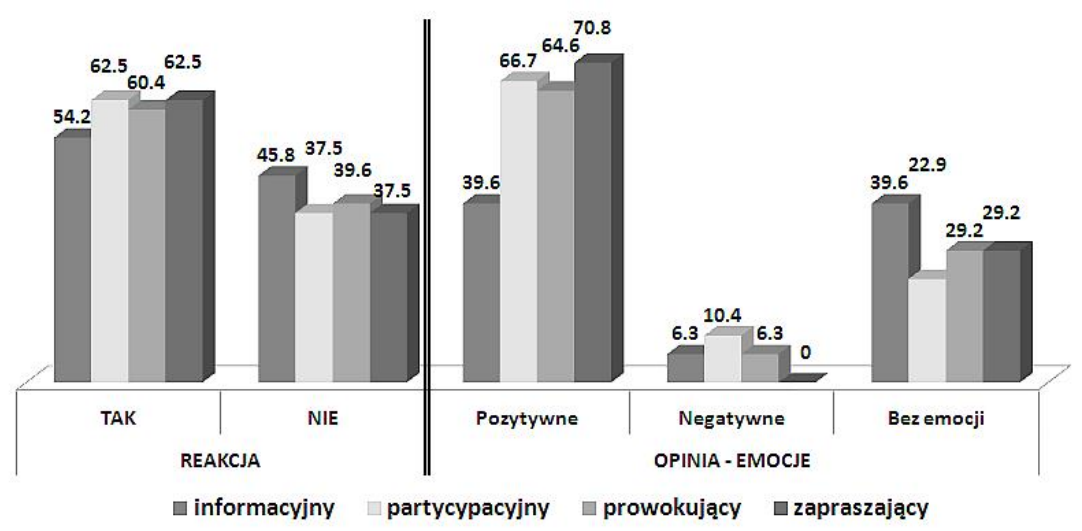

Wykres 6. Porównanie reakcji na posty i emocji, które deklarowali badani. Dane w procentach.

Dane wskazują, że można powiązać wyrażenie pozytywnych emocji z podjęciem działania online lub w świecie realnym. Wyliczenia procentowe są podobne dla emocji pozytywnych i zareagowania na tego rodzaju przekaz, największa rozbieżność występuje w przypadku posta informacyjnego. Z drugiej strony w każdej kategorii można również dostrzec korelację między procentowym wyrażeniem negatywnych emocji (na Wykresie 6 część REAKCJA, wskazanie na NIE) w przekazie z sumą wyboru opcji „bez emocji” oraz wykazania niechęci w podejmowaniu działania (zob. na Wykresie 6 część OPINIA-EMOCJE, suma wskazań Negatywne i Bez emocji). Różnice w procentach wynoszą $0,1 \mathrm{w}$ przypadku treści w kategorii informacje, 4,3 partycypacyjny, 3,8 prowokujący oraz 8,3 dla zapraszającego. Należy zaznaczyć, że w przypadku 48 ankietowanych osób 4\% to wypowiedź 2 osób (,w zaokrągleniu”) w liczbach bezwzględnych.

Warto podkreślić, że badanie wykazało korelację między konstrukcją postu i użyciem badanych elementów, ale tylko w przypadku przeciwnych wektorów emocji. Analiza komentarzy pokazuje, że można zdiagnozować kilka stopni istotności powyższych elementów. W cytowanych opiniach ankietowanych pojawiają się głosy świadczące o znaczeniu serwisów społecznościowych w komunikacji z samorządem lokalnym i „ludzkiej”, a nie „urzędowej” twarzy takiej interakcji. Na ten rodzaj kontaktów, „miasto-otoczenie", ma coraz większe znaczenie na ich emocjonalny odbiór. 


\section{BIBLIOGRAFIA}

Bazarova, Natalya, Yoon Choi, Victoria Schwanda Sosik, Dan Cosley, \& Janis Whitlock. „Social Sharing of Emotions on Facebook". CSCW '15: Proceedings of the 18th ACM Conference on Computer Supported Cooperative Work \& Social Computing, February 2015, 154-164. DOI: https://doi.org/10.1145/2675133.2675297.

Boyd, Danah M., \& Nicole B. Ellison. „Social Network Sites: Definition, History, and Scholarship". Journal of Computer - Mediated Communication, 13, Issue 1 (October 2007): 210 230. DOI: https://doi.org/10.1111/j.1083-6101.2007.00393.x.

Bоотн, Robert. „Facebook reveals news feed experiment to control emotions”. The Guardian. Dostęp 12.12.2019. https://www.theguardian.com/technology/2014/jun/29/facebook-users-emotionsnews-feeds.

„Cambridge Analytica”. Forbes. Dostęp 12.12.2019. https://www.forbes.pl/cambridge-analytica.

Chabrzyk, Agnieszka, \& Julia Kałużyńska, Przemysław Rosa, Andrzej Suhov, \& Monika Turek. „Facebook”, Przewodnik po social media w Polsce 2019/2020, iab Polska 2019, 6. Dostęp 01.01.2020. https://iab.org.pl/wp-content/uploads/2020/01/IAB-Przewodnik-po-Social-Media-wPolsce-2019-2020.pdf.

COHEN, Elizabeth, \& Alexander LANCASTER. „Individual differences in in-person and social media television coviewing: The role of emotional contagion, need to belong, and coviewing orientation". Cyberpsychology, Behavior, and Social Networking, 17(8) (2014): 512-518. DOI: https://doi.org/10.1089/cyber.2013.0484

„Emotikon”, Wielki słownik języka polskiego. Dostęp 12.12.2019. https://wsjp.pl/index.php?id_ hasla $=57204 \&$ ind $=0 \&$ w_szukaj=emotikon.

„Definition of emoji”. Słownik Merriam-Webster. Dostęp 12.12.2019. https://www.merriam-webster. com/dictionary/emoji.

Harding, Jenifer, \& E. Deidre Pribram (red. Emotions: A cultural studies reader. London: Routledge, 2009.

„Hasztag”. Wielki słownik języka polskiego. Dostęp: 12.12.2019. https://wsjp.pl/index.php?id _hasla $=86506 \&$ ind $=0 \& w_{-}$szukaj $=$hasztag + .

Hocking, John E., Duane G. Margreiter, \& Cal Hylton. „Intra-audience effects: A field test”. Human Communication Research, 3(3) 1977, 243-249. DOI: https://doi.org/10.1111/j.14682958.1977.tb00522.x.

Kemper, Theodore D. „How Many Emotions Are There? Wedding the Social and the Autonomic Components". American Journal of Sociology 93, no. 2 (1987): 263-289.

Kowalik, Krzysztof. „Dialog, monolog, interakcja? Portal społecznościowy jako kanał komunikowania online samorządu gminnego. Studium przypadku miasta Kielce”. Naukowy Przegląd Dziennikarski nr 3 (78) (2018): 7-25.

KowALIK, Krzysztof. „'Dystrybucja emocji’ jako forma komunikacji samorządów lokalnych w serwisie Facebook.com. Próba kategoryzacji przekazu w kontekście public relations". Studia Medioznawcze 3 (74) (2018): 51-63. DOI: https://doi.org/10.33077/uw.24511617.ms.2018.3.54.

Kowalik, Krzysztof. „Media online samorządów lokalnych — nowa struktura w systemie medialnym. Próba ujęcia in statu nascendi”. Zeszyty Prasoznawcze 61, nr 3 (235) (2018): 429-448.

KowALIK, Krzysztof. „Obowiązki informacyjne samorządu lokalnego w epoce mediów społecznościowych oraz trendy w implementacji w serwisach WWW kanałów dystrybucji informacji. Studium przypadku gmin świętokrzyskich”. Rocznik Bibliologiczno-Prasoznawczy nr 10 (21) (2018): 119-135. 
Kowalik, Krzysztof. „Serwisy społecznościowe w komunikacji samorządów lokalnych. Studium przypadku”. Naukowy Przegląd Dziennikarski nr 4 (24) (2017): 113-129.

KowALIK, Krzysztof. „Use of Information and Communication Technologies in Official Websites of Gminas. Are the Polish Rural and Rural-Urban Local Governments Prepared to Communicate with the Younger Generation — Digital Natives, Generation Y?". Public Administration Issues no. 5, 2019: 140-154. DOI: https://doi.org/10.17323/1999-5431-2019-0-5-140-154.

KrAmER, Adam D.I., Jamie E. Guillory, \& Jeffrey T. Hancock. „Experimental evidence of massive-scale emotional contagion through social networks". PNAS 111 (24) (June 17, 2014): 8788-8790. DOI: https://doi.org/10.1073/pnas.1320040111.

Krämer, Nicole C., German Neubaum, \& Sabrina C.A. Eimler. „Brief History of (Social) Cyberspace". W: Cyberemotions. Collective Emotions in Cyberspace, red. Janusz A. Hołyst, 11-35. Switzerland: Springer, Cham, 2017. DOI: https://doi.org/10.1007/978-3-319-43639-5.

KRIPPENDORF, Klaus. Content analysis an introduction to its methodology, 18-21. Thousand Oaks, London, New Delhi: SAGE, 2004.

LiN, Ruoyun, \& Sonja UTZ. „The emotional responses of browsing Facebook: Happiness, envy, and the role of tie strength". Computers in Human Behavior 52 (November 2015): 29-38. DOI: https://doi.org/10.1016/j.chb.2015.04.064.

Matz, Sandra, Michal Kosinski, Gideon NAVE, \& David J. Stillwell. „Psychological targeting as an effective approach to digital mass persuasion”. PNAS 114 (48) (November 28, 2017): 12714-12719. DOI: https://doi.org/10.1073/pnas.1710966114.

MCQuAIL, Denis. Teoria komunikowania masowego. Warszawa: Wydawnictwo Naukowe PWN, 2007.

Meyrowitz, Joshua. „Medium theory”. W: The Sage handbook of media processes and effects, red. Robin L. Nabi \& Mary Beth Oliver, 517-530. Los Angeles: Sage, 2009.

O'Reilly, Tim. „What is Web 2.0. Design Patterns and Business Models for the Next Generation of Sotware". O'Reilly.com. Dostęp 12.11.2019. http://www.oreilly.com/pub/a/web2/archive/ what-is-web-20.html?page $=1$.

„Polski internet w grudniu 2019”. Polskie Badania Internetu. Dostęp: 12.01.2020. http://pbi.org.pl/ badanie-gemius-pbi/polski-internet-w-grudniu-2019/.

PORĘBSKI, Mieczysław. Ikonosfera, 144-145. Warszawa: PIW, 1972.

Post informacyjny [zrzut ekranowy, gdyż post został usunięty z profilu samorządu]. Dostęp: 29.09.2019. https://drive.google.com/file/d/1pDCRgO2zsDR9wwdo0Z3zsPLtWxl4byaC/view? usp=sharing

Post partycypacyjny. Dostęp 27.09.2019. https://www.facebook.com/warszawa/videos/241861060 074222/

Post prowokujący. Dostęp 28.09.2019. https://www.facebook.com/warszawa/photos/p.10156742 823501270/10156742823501270/?type=1\&opaqueCursor=AbqQK_QHMcVFcEDGkvWv0O onIJPGc2kheBZ2kcZBu92kaW1tp2AIVIweHEGqfEYW-HCY7Is46tzJ6z-loim_brusa3x_r02yJ88 oYP78j54r_GQycEtLRm9JwyYz4CdDUALeAn26K11KGX3zoH5vvwf6amO1ik3Ht6wM1Q GOpAaDbka3zfadRLtAQWbGUyEFxhi53s5Fg8mVcicZK1Grz8njOzq5Ty-hLUkUHLTE GFJ2oSmrwAf-y_e8qth02715wyI6MYvH8wInE1BK4YkytvvBeualpnr8IdKHzHrmx7XODJsYm IT0 w2c4VibgHmiYG6S0g6eHeuY7IsjOf8XHKHwSBC6VO7yTA28GgtqEhKiziFAaDmazfm2O XuijtrkasOaPZRz3X615ixRSMcbAxYR1cE_iXOL28rwkf_gVrPZ1-1p98JFAJ_RIBX-GLgeam CFaqeBPqUwALa8YpIPPoV4PsXh_evHKq92T8TEN1wUAw.

Post zaproszenie. Dostęp 28.09.2019. https://www.facebook.com/ warszawa/videos/4038785671 70924/ 
RIMÉ, Bernard. The Social Sharing of Emotion in Interpersonal and in Collective Situations Cyberspace. W: Cyberemotions. Collective Emotions in Cyberspace, red. Janusz A. Hołyst, 53-69. Switzerland: Springer, Cham, 2017. DOI: 10.1007/978-3-319-43639-5

„Samorząd terytorialny w Polsce”. ADMINISTRACJA.mswia.gov.pl. Dostęp 12.01.2010. http://admi nistracja.mswia.gov.pl/adm/baza-jst/843,Samorzad-terytorialny-w-Polsce.html.

Silverman, David. Interpretacja danych ilościowych. Przełożyły Małgorzata Głowacka-Grajper \& Joanna Ostrowska, 59-62. Warszawa, Wydawnictwo Naukowe PWN 2008.

Smith, Kenneth L., Sandra Moriarty, Keith Kenney, \& Gretchen Barbatsis. Handbook of visual communication. Theory, methods, and media. New Jersey, London: Lawrence Erlbaum Associates, Inc., Publishers, 2005.

VINCENT, Jane, \& Leopoldina FORTUNATI (red.). Electronic emotion: the mediation of emotion via information and communication technologie. Oxford: Peter Lang, Internationaler Verlag der Wissenschaften, 2009.

\author{
EMOCJE JAKO ELEMENT STRUKTURY PRZEKAZU \\ SAMORZĄDU LOKALNEGO W SERWISIE FACEBOOK.COM \\ STUDIUM PRZYPADKU OFICJALNEGO PROFILU \\ MIASTA STOŁECZNEGO WARSZAWY
}

Streszczenie

Serwisy społecznościowe są coraz istotniejszym narzędziem komunikacji instytucji publicznych. Samorządy lokalne (władze gmin - miast) tworzą oficjalne profile społecznościowe, aby docierać nie tylko do swoich mieszkańców, ale także do turystów, inwestorów. Publikują treści o zróżnicowanym charakterze i zawartości. Z badań autora wynika, że przekaz ten można kategoryzować. Każdy rodzaj treści niesie ze sobą nie tylko porcję informacji, ale niektóre kategorie postów zawierają elementy, które mają za zadanie wzbudzać emocje i zarazem zaangażowanie użytkowników samorządowego profilu. Taki przekaz może zwiększać zasięg publikacji. Autor prezentuje wyniki swoich badań, wskazujących na preferowanie przez samorząd treści mogących inicjować wzmożoną, emocjonalną interakcję użytkowników serwisu Facebook.com. Studium przypadku (oficjalnego profilu Miasta Stołecznego Warszawy) stanowi próbę wskazania tych elementów struktury przekazu (postów), które mogą wzbudzać poruszenie wyrażane online w postaci „lajków”, komentarzy lub „,szerowania”.

Słowa kluczowe: samorząd lokalny; emocje w serwisie społecznościowym, struktura przekazu, reakcje użytkowników, Facebook.com.

\title{
EMOTIONS AS AN ELEMENT OF THE LOCAL GOVERNMENT MESSAGE STRUCTURE ON FACEBOOK.COM:
}

CASE STUDY OF THE OFFICIAL PROFILE OF THE CAPITAL CITY OF WARSAW

\section{S u m m a ry}

Social networking sites are an increasingly important communication tool for public institutions. Local governments (municipalities - cities) create official social profiles to reach not only their residents, but also tourists and investors. They publish content of diverse nature and 
content. The author's research shows that this message can be categorized. Each type of content brings not only a portion of information, but some categories of posts contain elements that are designed to arouse emotions and at the same time involve users of the local government profile. Such a message may increase the scope of publication. The author presents the results of his research showing that the local government prefers content that can initiate increased emotional interaction of Facebook.com users. The case study (Warsaw official profile) is an attempt to identify those elements of the message structure (posts) that may arouse online expression in the form of ,likes”, comments or „sharing”.

Key words: local government; emotions on the social network; message structure; user reactions; Facebook.com. 